\title{
ENTRE OS MUROS DA ESCOLA E DA UNIVERSIDADE: DISCUTINDO O ENSINO DE LÍNGUA PORTUGUESA E DE LITERATURA COM A PROFESSORA MARLI HERMENEGILDA PEREIRA
}

\begin{abstract}
Marli Hermenegilda Pereira
Doutora em Linguística pela Universidade Federal do Rio de Janeiro (UFRJ) Professora Associada da Universidade Federal Rural do Rio de Janeiro (UFRRJ)
\end{abstract}

Entrevistada por:

Everaldo Lima de Araújo Doutorando em Letras - Língua Portuguesa - pela Universidade do Estado do Rio de Janeiro (UERJ) ever.lima.araujo@gmail.com

Thiago Wallace Rodrigues dos Santos Lopes Mestrando em Letras - Língua Portuguesa - pela Universidade do Estado do Rio de Janeiro (UERJ) [Bolsista CAPES] thiagodossantos16@gmail.com

Marli Hermenegilda Pereira possui graduação em Letras pela Universidade Federal do Rio de Janeiro (UFRJ), mestrado e doutorado em Linguística também por essa Universidade. Atualmente é professora associada da Universidade Federal Rural do Rio de Janeiro (UFRRJ), atuando no curso de Letras, na área de Língua Portuguesa. É também professora do Mestrado Profissional em Letras (ProfLetras), do qual é vice-coordenadora. Tem experiência na área de variação linguística, atuando principalmente nos seguintes temas: ordenação de orações temporais, conectores temporais e ensino de língua portuguesa, com pesquisas e orientações que abordam variação linguística, gramaticalização, ensino de escrita e de oralidade. É autora de artigos publicados em periódicos nacionais e coautora dos livros Descrição e ensino de língua portuguesa: temas contemporâneos; Letramentos e multiletramentos na escola: teorias e práticas; Pesquisa e ensino: parceria ou dicotomia?; Futuro em letras: reflexões e estratégias de formação de professores na área de letras; e Estudos de processos de gramaticalização em português: metodologias e aplicações.

Ao longo do mês de junho, em meio a um contexto adverso, pandêmico, a professora Marli gentilmente se prontificou a conceder, via e-mail, esta entrevista à Palimpsesto. Nessa entrevista, discutiram-se questões de ensino de Língua Portuguesa e de Literatura, assim como aspectos da formação inicial do futuro docente nessa área, passando pela atual conjuntura universitária, dentre outras questões. 


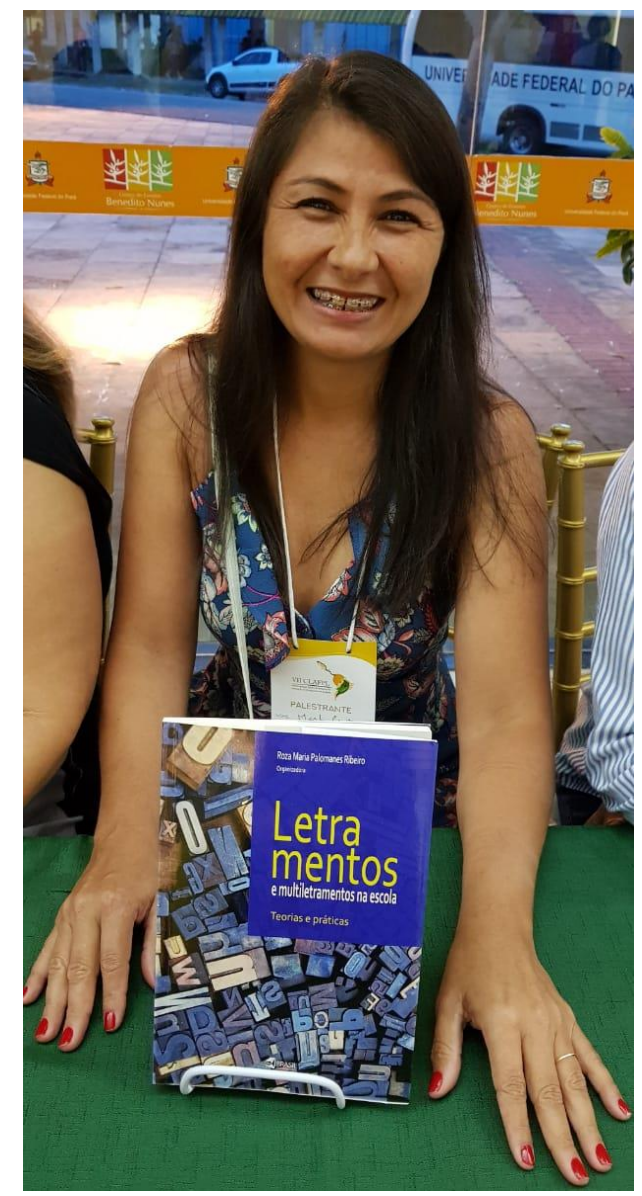

\section{PALIMPSESTO}

1) Como formadora de novos professores, qual o maior desafio quanto à formação docente na área do Ensino de Língua Portuguesa e de Literatura atualmente?

\section{MARLI HERMENEGILDA PEREIRA}

O desafio maior é conseguir conciliar formação de saberes e práxis docente. Isso ocorre, dentre vários outros motivos, porque o aluno ingressante, geralmente, não traz uma base sólida dos conteúdos linguísticos e literários necessários para seu aprofundamento, o que leva o docente a fazer uma retomada desses saberes, restringindo o tempo voltado para reflexão e desenvolvimento de estratégias de ensino. 


\section{PALIMPSESTO}

2) A senhora, além de atuar na graduação em Letras da Universidade Federal Rural do Rio de Janeiro (UFRRJ), compõe, também, o quadro de docentes do Mestrado Profissional em Letras dessa universidade. Pode nos dizer qual a importância desse programa para as inovações no Ensino de Língua Portuguesa e de Literatura?

\section{MARLI HERMENEGILDA PEREIRA}

O Mestrado Profissional em Letras (ProfLetras), em rede nacional, iniciou-se em 2013 com o propósito de melhorar a qualidade de ensino de Língua Portuguesa no ensino fundamental da rede pública no país. Além da tríade ensino de gramática, leitura e produção textual, com base em diversas abordagens teóricas, há também disciplinas voltadas para o ensino do texto literário. Se isso não pode ser considerado inovação é, pelo menos, um avanço, já que há uma preocupação com o ensino de textos literários, coisa que não é muito comum nos cursos de licenciatura em Letras.

Com base na minha experiência no ProfLetras/UFRRJ, pode-se dizer que a inovação ocorre mais em virtude da sistematização e aplicação de metodologias de ensino de Língua Portuguesa e de textos literários do que com o uso de ferramentas tecnológicas digitais. O professor pesquisador, ao desenvolver sua pesquisa em sala de aula, precisa estar ciente do contexto em que sua turma se insere, do seu perfil social e econômico, das suas dificuldades de aprendizagem e traçar estratégias de ensino para saná-las ou, pelo menos, minimizá-las. No âmbito do ensino de produção textual e de leitura, diversas pesquisas têm aplicado a Sequência Didática, proposta por Dolz e Schneuwly (2004); o mecanismo de retextualização, com base em Marcushi (2001) e Dell'Isolla (2007); abordagem da Aprendizagem Colaborativa, de Behrens (2004). No âmbito do ensino de fenômenos variáveis no português brasileiro, têm sido desenvolvidas 
sequências didáticas com base na proposta do contínuo fala e escrita de Marcushi (2001; 2008) e dos contínuos de variação linguística de Bortoni-Ricardo (2004).

Quanto ao uso didático das novas tecnologias, ainda há uma limitação em virtude de uma série de obstáculos que se apresenta: a escola não disponibiliza sinal de internet, os laboratórios de informática ficam fechados, ainda há muitos alunos sem celular ou com modelo que não suporta muitos aplicativos, etc. Tudo isso dificulta bastante a realização de atividades envolvendo as novas tecnologias. Mesmo com todas essas dificuldades, muitas pesquisas exploraram o uso do celular para atividades via whatsapp, utilização de aplicativos de preenchimento de currículo vitae (turmas da EJA), produção de jornal on-line através do blog escolar, dentre outras.

\section{PALIMPSESTO}

3) Pensando na sua experiência na sala de aula do ensino básico, do ensino superior e da pós-graduação, quais as possíveis interseções entre o ensino de Língua Portuguesa e o de Literatura e como ambos poderiam ser inovados numa sociedade cada vez mais envolta a tantas tecnologias?

\section{MARLI HERMENEGILDA PEREIRA}

Desde a divulgação dos Parâmetros Curriculares de Língua Portuguesa, em 1998, ficou patente que o ensino de língua só pode ocorrer por meio de textos, materializados em diversos gêneros textuais pertencentes a vários domínios discursivos: literário, midiático, acadêmico, dentre outros. Partindo dessa premissa, o trabalho de Língua Portuguesa pode explorar os textos literários não como pretexto para extração de informações gramaticais, como, geralmente, se faz, mas para ampliar o conhecimento de 
mundo do aluno, levá-lo a conhecer a estética do texto literário, desenvolver sua leitura crítica, despertar o gosto pela leitura, enfim, trabalhar o texto literário em sua imanência. Mais recentemente, houve a publicação da Base Nacional Comum Curricular BNCC - (2017) que reitera a perspectiva textual/interativa no ensino de Língua Portuguesa, potencializando o uso das novas tecnologias e indicando o ensino de diversos gêneros emergentes do contexto digital de natureza multissemiótica e multicultural. No tocante ao texto literário, enquanto objeto estético fundamental na formação do indivíduo, aparece de maneira mais consistente no texto da Base. A Literatura é apresentada como um campo de atuação (o artístico-literário) em todos os anos do Ensino Fundamental. O documento menciona, ainda, a importância do multiculturalismo na seleção dos textos: são recomendados desde os clássicos até as produções contemporâneas, passando pelas literaturas indígenas, africanas, afro-brasileiras, latinoamericanas e literatura universal.

Com base nessas orientações, o professor pode desenvolver atividades de leitura e produção de textos literários utilizando as potencialidades do ambiente digital. Algumas propostas interessantes são: a) produção de fanfiction - ficções criadas por fãs, que utilizam uma história ou personagens de um determinado trabalho já existente para criar sua própria história baseada nele. A história original pode ser um romance, série, filme, ou mesmo uma relação entre famosos; b) produção e leitura de Ciberpoema - poemas construídos em meio digital, que suportam animações e permitem, em muitos casos, a interação com a produção do autor e até a criação de novos textos; c) produção e leitura de nanocontos - narrativa breve e concisa, contendo um só conflito, uma única ação (com espaço geralmente limitado a um único ambiente), unidade de tempo, e número restrito de personagens. Embora sua criação seja anterior à era da internet, esse gênero se 
potencializou no meio digital devido à grande oferta de recursos. No Twitter, por exemplo, as postagens podem ter, no máximo, 140 caracteres.

Todas essas formas possibilitam a ampliação do letramento literário, já que, em sua maioria, têm como base o mecanismo da retextualização, transformação de um texto em outro, e/ou da intertextualidade.

\section{PALIMPSESTO}

4) Qual o lugar do texto literário nas aulas de Língua Portuguesa na educação básica?

\section{MARLI HERMENEGILDA PEREIRA}

O texto literário sempre esteve presente na educação básica. Nas séries iniciais, é comum o trabalho com poemas, contos de fadas, fábulas. Nas séries finais, amplia-se um pouco mais esse repertório com a inserção de contos e crônicas e até romances. No entanto, o texto literário nem sempre recebeu ou recebe papel central nas aulas, já que é usado, muitas vezes, como estereótipo/modelo para o reconhecimento das características estruturais e linguísticas de algum gênero/tipo textual ou é utilizado para extração de elementos gramaticais.

\section{PALIMPSESTO}

5) Os cursos de licenciatura em Letras discutem o Ensino de Literatura na mesma ênfase que o Ensino de Língua Portuguesa? Como a senhora vê essas reflexões na academia?

\section{MARLI HERMENEGILDA PEREIRA}


A própria pergunta já implica uma cisão entre essas duas áreas e uma atribuição de status diferenciado entre elas. Em termos de conteúdos e disciplinas não vejo disparidade entre elas, mas, no que tange ao ensino, sim. Geralmente, os cursos de licenciatura privilegiam o ensino de Língua Portuguesa, levantando reflexões sobre a prática docente e buscando metodologias mais eficientes para a área. Os cursos de Letras têm várias disciplinas para o estudo da Literatura, mas não para o ensino. O licenciado é preparado para ser leitor, teórico e crítico de Literatura, mas não para ensiná-la.

Acredito que isso ocorre basicamente por dois motivos. Em primeiro lugar, a separação entre conteúdo literário e conteúdo linguístico. Não costuma haver interdisciplinaridade entre essas duas áreas. Isso se reflete até no discurso de alguns alunos que falam "gosto de língua e não, de literatura" e vice-versa. A língua está presente nas mais variadas esferas comunicativas e a literatura e sua constelação de gêneros textuais é mais uma faceta dessa multifuncionalidade. A formação do professor deveria possibilitar uma interseção entre essas duas áreas, mas, muitas vezes, aumenta o fosso entre elas.

Em segundo lugar, em virtude da demanda social que exige o conhecimento das regras gramaticais da norma culta da língua nas mais variadas instâncias sociais e que requer um bom desempenho da capacidade leitora e escritora, o ensino de Língua Portuguesa acaba tendo mais atenção. Isso é um equívoco, pois essas habilidades podem ser potencializadas na medida em que o indivíduo, ao ter acesso aos bens culturais, dentre eles, o acervo literário, amplia seu repertório lexical e gramatical e seu conhecimento de mundo. Em seu texto, Direitos Humanos e Literatura, Antonio Candido, grande crítico literário brasileiro, defende o acesso à Literatura como um bem indispensável à sobrevivência humana, assim como a Alimentação, a Habitação e a 
Educação. Para ele, "a literatura confirma e nega, propõe e denuncia, apoia e combate, fornecendo a possibilidade de vivermos dialeticamente os problemas" (CANDIDO, 1989, p. 113). Assim, a Literatura é um instrumento poderoso de instrução e de educação e, por isso, o seu ensino carece de maior atenção.

\section{PALIMPSESTO}

6) A senhora é umas das autoras no livro Letramentos e multiletramentos na escola, sendo a responsável pelo capítulo teórico "Letramento e retextualização: conceitos e relações". Comente de que modo, na sua opinião, a retextualização contribui para o processo de letramento.

\section{MARLI HERMENEGILDA PEREIRA}

Como já apontei no livro, o processo de retextualização compreende a transformação de um texto em outro, resguardando suas principais informações. Pode ocorrer do oral para o escrito (aula expositiva - anotações da aula), do escrito para o oral (notícia impressa no jornal - relato oral), do oral para oral (peça de teatro - relato oral), da escrita para escrita (livro - resenha). Embora o processo seja complexo, já que envolve operações cognitivas, como compreensão e memória, está presente nas mais variadas situações cotidianas e se realiza, na maioria das vezes, de forma espontânea.

Em virtude disso, a transposição desse mecanismo para o ensino de leitura e de produção textual na escola é um importante recurso na ampliação do letramento do aluno por diversos motivos: "é uma atividade comum no dia a dia, permite o trabalho de consciência e de reflexão sobre as diferenças e semelhanças entre fala e escrita, propicia

o contato com gêneros textuais diversos, (...) favorece o trabalho com a língua em 
diversos níveis (ortografia, paragrafação, pontuação, aspectos gramaticais, vocabulário), requer recursos acessíveis para sua realização dentre outros" (PEREIRA, 2018, p. 75).

\section{PALIMPSESTO}

7) O mundo está vivendo uma situação conturbada e até inusitada para alguns. Quando pensamos em Brasil, vemos uma gama de iniciativas que buscam minimizar as defasagens relacionadas ao campo do Ensino. Como os multiletramentos podem ser benéficos nesse contexto?

\section{MARLI HERMENEGILDA PEREIRA}

As sociedades contemporâneas estão passando por uma das piores crises de saúde das últimas décadas, provocada pela pandemia do Covid-19. Nesse período crítico, a tecnologia tem se tornado uma poderosa aliada. Obrigadas ao isolamento social, as pessoas e as instituições precisaram recorrer a novas práticas de comunicação e a mudar comportamentos e hábitos. Por questão de sobrevivência, as diversas esferas sociais precisaram se adaptar para continuar as suas atividades: Educação (aulas on-line, transmissões ao vivo, reuniões virtuais, etc.), Comércio (vendas virtuais, entregas), Saúde (consultas on-line, prescrições virtuais), Trabalho (teletrabalho, pedido de auxílio emergencial), Religião (transmissões ao vivo de missas, cultos) Entretenimento (transmissões ao vivo de shows, eventos).

No âmbito da Educação, as escolas sofreram um grande impacto na medida em que foram "obrigadas" a realizar ensino remoto sem estarem preparadas e sem muito tempo para planejamento e operacionalização. A problemática é maior porque escancarou as desigualdades sociais, na medida em que deixou claro que milhares de 
alunos, principalmente das escolas públicas, não tinham acesso ou tinham acesso precário aos equipamentos tecnológicos e à internet.

Essa situação coloca em evidência a questão dos multiletramentos e a importância de a escola preparar o professor e os alunos para essas novas formas de interação. De acordo com Rojo (2012), os multiletramentos se caracterizam por formas de comunicação escrita que compreendem "a multiplicidade cultural das populações e a multiplicidade semiótica de constituição dos textos por meio dos quais ela se informa e se comunica (ROJO, 2012, p. 13)". Os gêneros que são produzidos e circulam no ambiente digital, geralmente, são multimodais, ou seja, conjugam várias semioses (imagens estáticas, imagens em movimentos, escrita, fala, desenho, dentre outros recursos) e, além disso, revelam várias formas de culturas (popular/erudita/de massa). São híbridos, interativos, fronteiriços, colaborativos, transgridem as relações de poder estabelecidas e, por isso, sua composição exige o desenvolvimento de práticas e capacidades para a compreensão e produção de diferentes linguagens, modos ou semioses. A BNCC já aponta para a necessidade de a escola tomar a seu cargo os novos letramentos emergentes na sociedade contemporânea.

Já em 1996, o grupo de estudiosos, denominados Nova Londres, defendia uma pedagogia dos multiletramentos para preparar o aluno para lidar com as situações atuais do mundo moderno, marcadas por conflitos culturais, raciais e sociais que reverberam no espaço escolar. Segundo eles, essas questões são tratadas com indiferença na sala de aula, o que ocasiona em mais violência e falta de perspectiva para os jovens. De acordo com esses estudiosos, a pedagogia dos multiletramentos pressupõe conceber a leitura e a escrita como formas de empoderamento e inclusão social. Filmes como "Escritores da liberdade" e "Pro dia nascer feliz", por exemplo, demonstram bem isso. Mostram a escola 
como um espaço de confronto de diferenças e de forças e apontam, como saída, práticas situadas de letramento: escrita e publicação de diários, no primeiro; e, no segundo, elaboração conjunta de fanzine ${ }^{1}$.

O enfrentamento dessas questões impõe muitos desafios aos professores e à escola. Em primeiro lugar, vivemos num país com enorme desigualdade social que também se revela no acesso desigual às ferramentas digitais. Seria preciso uma política pública de democratização e acesso às novas tecnologias. Enquanto isso não acontece, cabe ao professor mudar de postura e assumir seu papel de desbravador. Em segundo lugar, o currículo escolar ainda está preso ao cânone, ao trabalho com exemplares culturais tidos como erudito, central, dominante. O que se constata hoje são produções culturais híbridas, oriundas de diferentes letramentos (locais, globais, vernaculares, dominantes) e de diferentes campos (popular/ erudito/de massa). A escola precisa se abrir a essas formas de expressão, partir da realidade do aluno para ampliar seus horizontes. Em terceiro lugar, professores e alunos estão em níveis diferentes quanto ao uso dessas novas ferramentas. A maioria dos docentes não nasceu na era do boom tecnológico e é considerada como migrante digital, enquanto os alunos são nativos digitais, ou seja, lidam com mais facilidade com esses artefatos contemporâneos e são produtores e receptores de conteúdos. Então qual seria a contribuição do professor de línguas e da escola para essas novas gerações? O papel do professor é ajudar o aluno a desenvolver o letramento crítico, ou seja, torná-lo capaz de perceber os valores, as intenções, as estratégias discursivas, os efeitos de sentido, seja na recepção ou na produção de textos. Enfim, realizar um trabalho pedagógico com base nos multiletramentos é uma tarefa "hercúlea", mas urgente e necessária. 


\section{PALIMPSESTO}

8) As universidades baseiam-se em um tripé que compreende o Ensino, a Pesquisa e a Extensão. Particularmente, na área de Letras, como a senhora vê as ações desse tripé no âmbito do ensino de Língua Portuguesa e de Literatura?

\section{MARLI HERMENEGILDA PEREIRA}

Existem, pelo menos, dois Programas Nacionais oferecidos pelo Governo Federal, Programa de Educação Tutorial (PET) e Programa Institucional de Bolsa de Iniciação à Docência (Pibid), que têm propostas nesse sentido e estão presentes nas Universidades. O PET visa a desenvolver atividades de ensino, de pesquisa e de extensão sob uma perspectiva interdisciplinar. O Pibid objetiva proporcionar aos discentes do curso de licenciatura uma aproximação prática com o cotidiano das escolas públicas de educação básica e com o contexto em que elas estão inseridas. Há, ainda, as atividades de monitoria de algumas disciplinas do curso. Embora não estejam voltadas para a educação básica, permitem que o aluno, sob a orientação de um professor, elabore atividades didáticas, desenvolva estratégias de ensino e realize pesquisas oriundas desse processo de ensino e aprendizagem.

Além desses programas, há os programas de Iniciação Científica que visam a desenvolver o espírito científico do aluno. No entanto, vejo que as propostas vinculadas ao ensino ainda são tímidas, a maioria versa em torno de objeto de estudo das diversas áreas com base em alguma abordagem teórica.

Paralelo a essas atividades permanentes, os cursos oferecem uma gama de atividades voltadas para o tripé ensino/pesquisa/extensão não, necessariamente, articuladas. Existem eventos acadêmicos (Seminários, Congressos, Simpósios, dentre 
outros) que buscam a interface entre os conteúdos para a formação docente e o ensino, procurando levantar reflexões acerca de metodologias de ensino, material didático, dentre outras. Há também vários cursos de extensão, oferecidos por grupos de pesquisa ou por professores, individualmente, mas a maioria se volta para o aprofundamento ou para a complementação de conteúdos abordados nas diversas disciplinas. Há poucas iniciativas que articulem o conteúdo ao ensino.

Apesar dessa abundância de ofertas, noto que falta uma articulação maior entre os três pilares da Universidade (ensino/pesquisa/extensão) e uma maior interação entre as áreas de línguas e literaturas.

\section{PALIMPSESTO}

9) Que conselho(s) a senhora daria para aqueles que estão iniciando nas áreas de Letras e vislumbram trabalhar com o Ensino?

\section{MARLI HERMENEGILDA PEREIRA}

O ingressante do curso de Letras precisa aproveitar todas as oportunidades de acesso ao conhecimento e de crescimento acadêmico que a Universidade oferece. $\mathrm{O}$ diferencial no seu currículo não são as disciplinas cursadas, mas as atividades extracurriculares desenvolvidas. Existem inúmeros projetos de pesquisa, de extensão e de iniciação à docência, monitorias, eventos acadêmicos. É preciso buscar as informações e não esperar que elas venham até ele. O aluno deve, constantemente, acessar o site da Universidade, do seu curso, os grupos das redes sociais, procurar o coordenador do curso e os alunos veteranos para buscar essas informações. Pesquisar os grupos de pesquisas 
nos quais os professores estão inseridos e se mostrar interessado em participar, enfim, precisa estabelecer, desde o início, uma rede de contato, não se pode ficar isolado.

A postura do aluno enquanto aluno também conta muito, porque já demonstra se será alguém comprometido com sua formação profissional e acadêmica, se apresenta uma atitude ética diante das situações, se demonstra zelo e dedicação em realizar as atividades propostas, se respeita os prazos de entrega dos trabalhos, se procura trabalhar de forma cooperativa com os demais colegas. Tudo isso é observado pelos pares. Tudo que se faz de bom ou ruim rapidamente circula pela academia. $\mathrm{O}$ aluno deve procurar construir uma imagem positiva de si.

O investimento na formação também deve ser prioridade. O aluno deve abdicar de certos hábitos de consumo e procurar, ao longo do curso, adquirir seu acervo de pesquisa e de estudo. Ter as principais gramáticas (normativas e descritivas), dicionários especializados na área de Linguística e de Literaturas. Buscar ler os clássicos universais e nacionais, mesmo que não seja da área de Literaturas, porque as diversas manifestações artísticas, culturais e sociais contemporâneas dialogam com esse patrimônio. O professor de línguas e literaturas precisa ter esse conhecimento prévio para fazer uma mediação de ensino de língua consciente e reflexiva.

E, por último, o aluno, futuro professor, deve se esforçar para desenvolver a empatia, ter sensibilidade e aceitação do outro, se despir de preconceitos para olhar a realidade social, linguística e cultural do seu futuro aluno com respeito. A relação ensino e aprendizagem perpassa por esses valores. 


\section{Referências}

BEHRENS, Maria Aparecida. Projetos de aprendizagem colaborativa num paradigma emergente. In: MORAN, José Manuel. Novas tecnologias e mediação pedagógica. Campinas, SP: Papirus, 2004. p. 67-102

BORTONI-RICARDO, Stella Maris. Educação em língua materna: a sociolinguística em sala de aula. São Paulo: Parábola Editorial, 2004.

BUZEN, Clecio; MENDONÇA, Márcia. (org.). Múltiplas linguagens para o ensino médio. São Paulo: Parábola Editorial, 2013.

CANDIDO, Antonio. Direitos humanos e literatura. In: A. C. R. Fester (org.). Direitos humanos E... Cjp / São Paulo: Brasiliense, 1989. Disponível em:

$<$ http://homoliteratus.com/antonio-candido-o-direito-humano-literatura/>. Acesso em: 19 jun. 2020.

DOLZ, J.; SCHNEUWLY, B. (org.). Gêneros orais e escritos na escola. Tradução e organização Roxane Rojo e Glaís Sales Cordeiro. Campinas, SP: Mercado das Letras, 2004.

MARCUSCHI, Luiz Antônio. Da fala para a escrita: atividades de retextualização. 2. ed. São Paulo: Cortez, 2001.

MARCUSCHI, Luiz Antônio. Produção textual, análise de gêneros e compreensão. São Paulo: Parábola Editorial, 2008.

PEREIRA, Marli H. Letramento e retextualização: conceitos e relações. In. RIBEIRO, Roza Palomanes. Letramentos e multiletramentos na escola: teorias e práticas. Campos de Goytacazes, RJ: Brasil Multicultural. 2018, p. 54-77.

ROJO, Roxane. Pedagogia dos multiletramentos: diversidade cultural e de linguagem na escola. In: ROJO, R. ; MOURA, E. (orgs.). Multiletramentos na escola. São Paulo: Parábola Editorial, 2012. p. 11-31. 


\title{
BETWEEN AND BEYOND THE WALLS OF THE SCHOOL AND OF THE UNIVERSITY: A DISCUSSION WITH PROFESSOR MARLI HERMENEGILDA PEREIRA ABOUT LITERATURE AND PORTUGUESE LANGUAGE TEACHING
}

\begin{abstract}
Marli Hermenegilda Pereira
PhD in Linguistics (Universidade Federal do Rio de Janeiro, UFRJ) Associate Professor at the Universidade Federal Rural do Rio de Janeiro, UFRRJ
\end{abstract}

Interviewed by:

Everaldo Lima de Araújo

PhD student in Letters - Portuguese Language (Universidade do Estado do Rio de Janeiro) ever.lima.araujo@gmail.com

Thiago Wallace Rodrigues dos Santos Lopes MA student in Letters - Portuguese Language (Universidade do Estado do Rio de Janeiro) thiagodossantos16@gmail.com

Translated by:

Thales Sant'Ana Ferreira Mendes MA in Literary Studies, Brazilian Literature (Universidade do Estado do Rio de Janeiro,

thales.sanfer@hotmail.com

Marcela Santos Brigida PhD Student in Literary Studies at UERJ. CNPq Scholar. marcela.brigida@uerj.br

Marli Hermenegilda Pereira holds a BA in Letters as well as an MA and a PhD in Linguistics (UFRJ). She is an Associate Professor at the Universidade Federal Rural do Rio de Janeiro, where she teaches Portuguese. She also acts as a Professor and a ViceCoordinator at ProfLetras, a postgraduate program in the same area. She is a specialist on linguistic variation, chiefly on the following themes: the ordering of temporal clauses, 
Marli Hermenegilda Pereira, Everaldo L. de Araújo, Thiago Wallace Rodrigues dos Santos Lopes, Thales Sant'Ana Ferreira Mendes, Marcela Santos Brigida

temporal connectors and Portuguese language teaching. Her researches address linguistic variation, grammaticalization, as well as the teaching of writing and of orality. She is author of many articles e co-author of the books Descrição e ensino de língua portuguesa: temas contemporâneos; Letramentos e multiletramentos na escola: teorias e práticas; Pesquisa e ensino: parceria ou dicotomia?; Futuro em letras: reflexões e estratégias de formação de professores na área de letras; and Estudos de processos de gramaticalização em português: metodologias e aplicações.

In June, in the midst of an adverse, pandemic context, Professor Marli kindly talked to Palimpsesto via e-mail. Throughout the interview, we have discussed Portuguese Language and Literature teaching and the initial training of new teachers in this area. We have also addressed the issues the university faces today, among other questions.

\section{PALIMPSESTO}

1) What is the biggest challenge for someone who instructs new teachers in the area of Portuguese Language and Literature today?

\section{MARLI HERMENEGILDA PEREIRA}

The biggest challenge is to ally formation of knowledge and teaching praxis. This is so, among several other reasons, because the incoming student does not usually bring a solid base of linguistic and literary contents which are necessary for further study. This leads the professor to revise all this knowledge, restraining the amount of time dedicated to the reflection and development of teaching strategies. 


\section{PALIMPSESTO}

2) Besides working as a Professor in the undergraduate program in Letters at Universidade Federal Rural do Rio de Janeiro, you are also a member of the faculty of a postgraduate program at the same university. Could you tell us how important this program is for innovations in Portuguese Language and Literature Teaching?

\section{MARLI HERMENEGILDA PEREIRA}

The professional master's degree program in Letters (ProfLetras) was inaugurated in 2013 with the purpose of improving the quality of Portuguese language teaching in Brazil's public elementary education. Besides the triad that involves grammar teaching, reading and textual production, which is based on several theoretical approaches, there are also subjects focused on the teaching of literary texts. If this cannot be considered an innovation, it is at least an improvement, since there is a concern with the teaching of literary texts, something that is not very common in Letters licentiateship courses.

Based on my experience at Profletras, I can say that the improvement has more to do with the systematization and application of teaching methodologies of Portuguese language and of literary texts, than with the use of digital technological tools. The researcher-professor, when developing his research at the classroom, must be aware of the context of which his class is a part of, as well as its social and economic profile and its learning difficulties, in order to elaborate teaching strategies to repair those elements, or, at least, to minimize them. In the context of teaching textual production and reading, several researches have been applying the Didactic Sequence, proposed by Dolz e Schneuwly (2004); the mechanism of retextualization, based on Marcushi (2001) and Dell'Isolla (2007); the Collaborative Learning approach, by Behrens (2004). In the context of teaching variable phenomena in Brazilian Portuguese, didactic sequences based on 
Marcuschi's (2001, 2008) speaking-writing continuum, and on Bortoni-Ricardo's (2004) linguistic variations continuums have been developed.

Regarding the use of new technologies for didactic purposes, there is still a limitation due to a series of possible obstacles: the school does not have an internet connection available, the computer labs remain closed, there are still many students who do not have a mobile or who own a model that does not support many applications, etc. All these elements make it very difficult to carry out activities involving new technologies. Despite all those difficulties, many researches have explored the utilisation of mobiles for activities via WhatsApp, the utilisation of applications to fill out a curriculum vitae (EJA classes), the production of online newspapers through the school blog, among other initiatives.

\section{PALIMPSESTO}

3) Considering your experience at the classroom in elementary schools, what are the possible intersections between the teaching of Portuguese and that of Literature? How could both be innovative in a society increasingly surrounded by so many different technologies?

\section{MARLI HERMENEGILDA PEREIRA}

Since the release of the Portuguese Language Curriculum Parameters, in 1998, it has become clear that language teaching can only occur through texts, materialised in several textual genres belonging to various discursive domains: literary, mediatic, academic, among others. Based on this premise, the work on Portuguese Language can explore literary texts not as a pretext for extracting grammatical information, as it is usually done, but to expand the student's knowledge of the world. In other words, to lead 
him to get to know the aesthetics of the literary text, to develop his critical reading, to awaken his taste for reading, in short, to work on the literary text in its immanence.

More recently, the Base Nacional Comum Curricular - BNCC [National Common Curricular Base] (2017) was issued. It reiterates the textual / interactive perspective in the teaching of the Portuguese language, potentialising the use of new technologies and indicating the teaching of several genres emerging from the digital context of a multisemiotic and multicultural nature. Regarding the literary text, as a fundamental aesthetic object in the formation of the individual, it is featured more consistently in the text of the BNCC. Literature is presented as a field of action (the artistic-literary one) in all the years of elementary school. The document also mentions the importance of multiculturalism in the selection of texts: it recommends productions that range from classics to contemporary artworks, including indigenous, African, Afro-Brazilian, Latin American and universal literature.

Based on these guidelines, the teacher can develop activities for reading and producing literary texts using the potentialities of the digital environment. Some interesting proposals are: a) fan fiction production - pieces of fiction created by fans, who use a story or characters from a given existing work to create their own story based on it. The original story can be a novel, a TV series, a film, or even a relationship between famous people; b) the production and reading of a cyberpoem - poems built in digital media, which support animations and allow, in many cases, interaction with the author's production and even the creation of new texts; c) the production and reading of nano stories - a short and concise narrative, containing a single conflict, a single action (space is usually limited to a single environment), a single time unit, and a restricted number of characters. Although its creation is prior to the internet age, this genre has been 
potentialised in the digital environment due to the large supply of resources. On Twitter, for example, posts can have a maximum of 140 characters.

All these forms enable the expansion of literary literacy, since, for the most part, they are based on the mechanism of retextualisation, transformation of one text into another, and / or intertextuality.

\section{PALIMPSESTO}

4) What is the place of the literary text in Portuguese Language classes in elementary education?

\section{MARLI HERMENEGILDA PEREIRA}

The literary text has always been present in elementary education. In the initial grades, it is common to work with poems, fairy tales and fables. In the later grades, this repertoire is expanded a little more, including short stories, chronicles and even novels. However, the literary text has not always received a central role in classes, as it is often used as a stereotype / model for the recognition of structural and linguistic characteristics of some genre / textual type or it is used for the extraction of grammatical elements.

\section{PALIMPSESTO}

5) Do licentiateship Letters courses discuss the teaching of Literature with the same emphasis as the teaching of Portuguese Language? How do you see these reflections in academia?

\section{MARLI HERMENEGILDA PEREIRA}


The question itself already implies a split between those two areas and an attribution of a different status between them. In terms of content and courses, there are no differences between them, but, regarding their teaching element, the differences are there. In general, licentiateships focus on the teaching of Portuguese, raising reflections about teaching practices and seeking methodologies that are more efficient for the area. Letters courses have several classes dedicated to the study of Literature, but not to its teaching. The licentiate professional is prepared to act as a reader, a theorist and a critic of literature, but not to teach it.

I believe this occurs basically for two reasons. Firstly, it is due to the separation between literary and linguistic content. There is usually no interdisciplinarity between those two areas. This is even reflected in the discourse of some students, who will say "I like languages, but not literature" and vice versa. The language is present in the most varied communicative spheres, and literature and its constellation of textual genres is yet another facet of this multifunctionality. Teacher training should allow for an intersection between those two areas, but it often increases the gap between them.

Secondly, due to the social demand that requires knowledge of grammatical rules of the cultured norm of language in the most varied social instances, as well as a good performance of the reading and writing ability, the teaching of Portuguese language ends up receiving more attention. This is a mistake, as these skills can be enhanced to the extent that the individual, when having access to cultural goods, including the literary collection, expands his lexical and grammatical repertoire and his knowledge of the world. In Direitos Humanos e Literatura ["Human Rights and Literature"], Antonio Candido, a great Brazilian literary critic, defends the access to Literature as an indispensable asset to human survival, as well as Food, Housing and Education. According 
Marli Hermenegilda Pereira, Everaldo L. de Araújo, Thiago Wallace Rodrigues dos Santos Lopes, Thales Sant'Ana Ferreira Mendes, Marcela Santos Brigida

to him, "literature confirms and denies, proposes and denounces, supports and contradicts, providing the possibility of experiencing problems dialectically"2 (CANDIDO, 1989, p. 113). Therefore, literature is a powerful instrument of instruction and education and, therefore, its teaching needs more attention.

\section{PALIMPSESTO}

6) You are one of the authors of the book Letramentos e multiletramentos na escola, having written the theoretical chapter "Letramento e retextualização: conceitos e relações". Could you tell us how, in your opinion, does retextualisation contribute to the literacy process?

\section{MARLI HERMENEGILDA PEREIRA}

As I have argued in the book, the retextualisation process involves the transformation of one text into another, safeguarding its main information. It can occur from the oral to the written form (expository class - class notes), from the written to the oral form (news printed in the newspaper - oral report), from the oral to the oral form (theatre play - oral report), from the written to the written form (book - review). Although the process is complex, as it involves cognitive operations, such as comprehension and memory, it is present in the most varied everyday situations and is carried out, most of the time, spontaneously.

As a result, the transposition of this mechanism to the teaching of reading and textual production at school is an important resource in expanding student literacy for several reasons: "it is a common activity in everyday life, it allows the work of conscience and reflection on the differences and similarities between speech and writing, it provides contact with different textual genres, (...) it favours working with the language at 
different levels (spelling, paragraphing, punctuation, grammatical aspects, vocabulary), it requires accessible resources for its realisation, among others "(PEREIRA, 2018, p. 75) ${ }^{3}$.

\section{PALIMPSESTO}

7) The world is experiencing a troubled and even unusual situation for some. Thinking of Brazil, we find a range of initiatives that seek to minimize the gaps related to the field of Education. How can multiliteracies help in this context?

\section{MARLI HERMENEGILDA PEREIRA}

Contemporary societies are going through one of the worst health crises in decades, which has been caused by the Covid-19 pandemic. In this critical period, technology has become a powerful ally. Forced into social isolation, people and institutions had to resort to new communication practices and to change behaviours and habits. As a matter of survival, the different social spheres had to adapt to maintain their activities: Education (online classes, live broadcasts, virtual meetings, etc.), Commerce (virtual sales, home deliveries), Health (online consultations, virtual prescriptions), Work (working from home, requests for government-issued emergency assistance packages), Religion (live broadcasts of masses, services) Entertainment (live broadcasts of concerts, events).

In the scope of Education, schools have suffered a great impact as they were "forced" to carry out a transposition to remote education without being prepared and with little time for planning and operationalisation. The problem was amplified as it exposed social inequalities, insofar as it made it clear that thousands of students, mainly those attending public schools, did not have access or had precarious access to technological equipment and the internet. 
This situation highlights the question of multiliteracies and the importance of schools preparing teachers and students for the new forms of interaction. According to Rojo (2012), multiliteracies are characterised by forms of written communication that comprise "the cultural multiplicity of populations and the semiotic multiplicity of the constitution of the texts through which it is informed and communicated" (ROJO, 2012, p. $13)^{4}$. The genres that are produced and that circulate in the digital environment are generally multimodal, that is, they combine several semioses (static images, moving images, writing, speech, drawing, among other resources) and, in addition, reveal various forms of cultures (popular / erudite / mass). They are hybrid, interactive, borderline, collaborative. They transgress the established power relations and, therefore, their composition requires the development of practices and capacities for the understanding and production of different languages, modes or semioses. BNCC has already signalled the need for schools to take charge of new emerging literacies in contemporary society.

In 1996, the New London group of scholars defended a pedagogy of multiliteracies to prepare students to handle current situations in the modern world, marked by cultural, racial and social conflicts that reverberate in the school space. According to them, these issues are treated with indifference in the classroom, which causes more violence and a lack of perspective for young people. According to those scholars, the pedagogy of multiliteracies presupposes conceiving reading and writing as forms of empowerment and social inclusion. Films such as Freedom Writers and Pro dia nascer feliz, for instance, demonstrate this well. They show the school as a space for confronting differences and forces and point to situated practices of literacy as a solution: writing and publishing diaries, in the former; and joint fanzine ${ }^{5}$ development in the latter. 
Facing these issues poses many challenges for teachers and the school. Firstly, we live in a country with enormous social inequality that is also revealed in the unequal access to digital tools. Public policy of democratisation and access to new technologies would be necessary. In the meantime, it is up to the teacher to change his posture and assume his role as a pioneer. Secondly, the school curriculum is still tied to the canon, to working with cultural examples considered to be erudite, central, dominant. What we see today are hybrid cultural productions, coming from different literacies (local, global, vernacular, dominant) and from different fields (popular / erudite / mass). The school needs to be open to these forms of expression, departing from the students' reality to broaden their horizons. Thirdly, teachers and students are at different levels in the use of these new tools. Most teachers were not born in the era of the technological boom and are considered to be digital migrants, while students are digital natives, that is, they deal more easily with these contemporary artefacts and are content producers and recipients. So, what would be the contribution of the language teacher and of the school to these new generations? The teacher's role is to help students to develop critical literacy, that is, to make them capable of perceiving values, intentions, discursive strategies, the effects of meaning, whether in the reception or in the production of texts. Finally, carrying out a pedagogical work based on multiliteracies is a "herculean" task, but an urgent and necessary one.

\section{PALIMPSESTO}

8) Universities are based on a tripod that comprises teaching, research and extensionist activities. Particularly, in the area of Letters, how do you see the actions of this tripod in the context of teaching Portuguese and Literature? 


\section{MARLI HERMENEGILDA PEREIRA}

There are at least two National Programs provided by the Brazilian Federal Government, the Programa de Educação Tutorial [Tutorial Education Program] (PET) and the Programa Institucional de Bolsa de Iniciação à Docência [Institutional Teaching Initiation Scholarship Program] (Pibid), which have proposals in this regard and are present in universities. PET aims to develop teaching, research and extensionist activities from an interdisciplinary perspective. Pibid aims to provide undergraduate students with a practical approach to the daily lives of public basic education schools and the context in which they are inserted. There are also tutoring activities for some subjects in the course. Although those are not focused on basic education, they allow the student, under the guidance of a teacher, to create didactic activities, to develop teaching strategies and to conduct research that originate from this teaching and learning process.

In addition to these programs, there are Scientific Initiation programs that aim to develop the student's scientific spirit. However, I see that the proposals linked to teaching are still timid, most of them are about objects of study in different areas based on theoretical approaches.

Parallel to those permanent activities, the courses offer a range of activities aimed at the teaching / research / extension tripod, which are not necessarily articulated. There are academic events (Seminars, Congresses, Symposiums, among others) that seek the interface between those contents for teacher training and teaching, seeking to propose reflections on teaching methodologies, didactic material, among others. There are also several extensionist courses, offered by research groups or by professors, individually, but 
the majority are aimed at deepening or complementing the content covered in the various classes. There are few initiatives that link content to teaching.

Despite this abundance of offers, I have noticed that there is a lack of greater articulation between the three pillars of the University (teaching / research / extensionist activities) and a greater interaction between the areas of languages and literature.

\section{PALIMPSESTO}

9) What advice would you give to those who are starting in the area of Letters and would like to work as teachers?

\section{MARLI HERMENEGILDA PEREIRA}

The student that begins his education in a Letters course needs to take advantage of all the opportunities to access to knowledge and academic growth that the university offers. What makes a difference in a student's curriculum are not the subjects taken, but the extracurricular activities developed. There are countless research, extensionist and teaching initiation projects, as well as tutoring opportunities, and academic events. It is necessary to seek out information instead of waiting until it finds you. Students must constantly access the university's website, the webpage for their college or institute, as well as social media groups. They must find the course coordinator and veteran students to look for information. It is also important to look up the research groups in which the teachers take part and to show an interest in participating. In short, you need to establish a network from the beginning, you cannot isolate yourself. 
The student's attitude as a student also counts a lot, as it shows whether someone will be committed to their professional and academic training, if they have an ethical attitude in the face of different situations, if they show zeal and dedication to carry out proposed activities, if the deadlines are respected, if they work cooperatively with other colleagues. All this is observed by peers. Everything that is done, good or bad, quickly circulates through academia. The students should try to build a positive image of themselves.

Investment in education must also be a priority. Students must give up certain consumption habits and seek, throughout the course, to acquire their collection for research and study. They should own copies of the main grammars (normative and descriptive), specialised dictionaries in the area of Linguistics and Literature. They must try to read the universal and national classics, even if not in the area of Literature, as the various contemporary artistic, cultural and social manifestations establish a dialogue with this heritage. Languages and literature teachers need to have this prior knowledge to mediate conscious and reflective language teaching.

And, finally, students, future teachers, must strive to develop empathy and to have sensitivity and acceptance of others, to free themselves of any prejudice to look at the social, linguistic and cultural reality of their future students respectfully. The teaching and learning relationship runs through these values.

\section{Works Cited}

BEHRENS, Maria Aparecida. Projetos de aprendizagem colaborativa num paradigma emergente. In: MORAN, José Manuel. Novas tecnologias e mediação pedagógica. Campinas, SP: Papirus, 2004. p. 67-102 
BORTONI-RICARDO, Stella Maris. Educação em língua materna: a sociolinguística em sala de aula. São Paulo: Parábola Editorial, 2004.

BUZEN, Clecio; MENDONÇA, Márcia. (org.). Múltiplas linguagens para o ensino médio. São Paulo: Parábola Editorial, 2013.

CANDIDO, Antonio. Direitos humanos e literatura. In: A. C. R. Fester (org.). Direitos humanos E... Cjp / São Paulo: Brasiliense, 1989. Disponível em:

<http://homoliteratus.com/antonio-candido-o-direito-humano-literatura/>. Acesso em: 19 jun. 2020.

DOLZ, J.; SCHNEUWLY, B. (org.). Gêneros orais e escritos na escola. Tradução e organização Roxane Rojo e Glaís Sales Cordeiro. Campinas, SP: Mercado das Letras, 2004.

MARCUSCHI, Luiz Antônio. Da fala para a escrita: atividades de retextualização. 2. ed. São Paulo: Cortez, 2001.

MARCUSCHI, Luiz Antônio. Produção textual, análise de gêneros e compreensão. São Paulo: Parábola Editorial, 2008.

PEREIRA, Marli H. Letramento e retextualização: conceitos e relações. In. RIBEIRO, Roza Palomanes. Letramentos e multiletramentos na escola: teorias e práticas. Campos de Goytacazes, RJ: Brasil Multicultural. 2018, p. 54-77.

ROJO, Roxane. Pedagogia dos multiletramentos: diversidade cultural e de linguagem na escola. In: ROJO, R. ; MOURA, E. (orgs.). Multiletramentos na escola. São Paulo: Parábola Editorial, 2012. p. 11-31.

\footnotetext{
${ }^{1}$ Fanzine - trata-se de publicações (Revista de fã) desenvolvidas com poucos recursos financeiros e que se destinam a divulgação de artes de fãs (história em quadrinhos, cinema, mangás, música, etc.), normalmente, fora do circuito comercial (Cf. BUNZEM; MENDONÇA, 2013).

${ }^{2}$ This quote has been translated by Palimpsesto's editors.

${ }^{3}$ This quote has been translated by Palimpsesto's editors.

${ }^{4}$ This quote has been translated by Palimpsesto's editors.

${ }^{5}$ Fanzines are publications (Fan Magazine) developed with little financial resources and intended to promote fan art (comics, cinema, mangas, music, etc.), usually outside the commercial circuit (Cf. BUNZEM; MENDONÇA, 2013).
} 